\title{
Hyperchloremic Metabolic Acidosis Following Total Gut Irrigation with Normal Saline in Pediatric Patients: A Rare Occurrence
}

\author{
Indu Bala, Deepak Dwivedi', Divya Jain, Jai Kumar Mahajan² \\ Departments of Anaesthesia and Intensive Care and ${ }^{2}$ Paediatric Surgery, Post Graduate Institute and Medical Education Research, Chandigarh, ${ }^{1}$ Department of \\ Anaesthesia and Critical Care, Institute of Naval Medicine, INHS Asvini, Mumbai, Maharashtra, India
}

\section{Abstract}

Use of $0.9 \%$ sodium chloride for total gut irrigation (TGI) through nasogastric route is an effective method of bowel preparation in children undergoing colorectal surgeries. TGI with normal saline (NS) can result in nausea, vomiting, abdominal distension, and mild electrolyte imbalance; however, hyperchloremic metabolic acidosis has not been documented. We report two cases of hyperchloremic metabolic acidosis in children posted for colorectal surgery following TGI with NS who were successfully managed.

Key words: Acidosis, anion gap, anorectal malformation, balanced salt solution, pediatrics, rectovaginal fistula, water-electrolyte imbalance

\section{INTRODUCTION}

Total gut irrigation (TGI) through nasogastric route is a rapid, safe, and effective method of bowel preparation in children undergoing colorectal surgeries. ${ }^{[1]}$ Various solutions available for TGI include Ringer lactate, polyethylene glycol, and mannitol but $0.9 \%$ sodium chloride (normal saline [NS]) is widely used because it is safe, effective, affordable, and readily available. ${ }^{[2]}$

The side effects observed after TGI with NS are nausea, vomiting, abdominal distension, weight gain, and mild electrolyte imbalance. ${ }^{[3-5]}$ We have not come across any report of hyperchloremic metabolic acidosis following TGI with NS. We report two cases of hyperchloremic metabolic acidosis following TGI with NS.

\section{Case Reports}

\section{Case report 1}

A 3-year-old healthy male child weighing $15 \mathrm{~kg}$ was posted for Duhamel procedure for Hirschsprung disease. His preoperative hemoglobin was $11 \mathrm{~g} / \mathrm{dl}$, serum sodium (Na) $140 \mathrm{mmol} / \mathrm{L}$, and chloride $(\mathrm{Cl}) 100 \mathrm{mmol} / \mathrm{L}$. An evening before surgery, TGI

\begin{tabular}{|l|l|}
\hline \multicolumn{2}{|c|}{ Access this article online } \\
\hline Quick Response Code: & Website: \\
\hline & www.ijccm.org \\
\hline & \\
\hline
\end{tabular}

was started through nasogastric tube and $4.5 \mathrm{~L}$ of NS was used over a period of $10 \mathrm{~h}$. On the morning of surgery, the child was found to be lethargic. He vomited once before induction of general anesthesia. The surgery was uneventful. On completion of surgery, the patient was reversed with intravenous (IV) neostigmine $50 \mathrm{mcg} / \mathrm{kg}$ and $10 \mathrm{mcg} / \mathrm{kg}$ glycopyrrolate. After reversal though the child had adequate tidal volume, but he was not responding to commands or moving his limbs. An arterial blood gas sample (ABG) which was sent to rule out electrolyte imbalance showed $\mathrm{pH} 7.05, \mathrm{PaO}_{2} 92.4 \mathrm{mmHg}$, $\mathrm{PaCO}_{2} 40 \mathrm{mmHg}$, Na $132 \mathrm{mmol}, \mathrm{K} 3.5 \mathrm{mmol} / \mathrm{L}, \mathrm{Cl} 117 \mathrm{mmol} / \mathrm{L}$, bicarbonate $\left(\mathrm{HCO}_{3}\right) 11 \mathrm{mmol} / \mathrm{L}$, and base excess (BE)-18.9.

An IV infusion of $5 \%$ dextrose in water with $50 \%$ of the calculated amount of sodium bicarbonate $\left(\mathrm{NaHCO}_{3}\right)$ was started. The child showed improvement and started responding

Address for correspondence: Dr. Deepak Dwivedi, Department of Anaesthesia and Critical Care, Institute of Naval Medicine, INHS Asvini, Colaba, Mumbai - 400 005, Maharashtra, India. E-mail: deepakdwivedi739@gmail.com

This is an open access article distributed under the terms of the Creative Commons Attribution-NonCommercial-ShareAlike 3.0 License, which allows others to remix, tweak, and build upon the work non-commercially, as long as the author is credited and the new creations are licensed under the identical terms.

For reprints contact: reprints@medknow.com

How to cite this article: Bala I, Dwivedi D, Jain D, Mahajan JK. Hyperchloremic metabolic acidosis following total gut irrigation with normal saline in pediatric patients: A rare occurrence. Indian J Crit Care Med 2017;21:55-6. 
to commands and was extubated. His $\mathrm{ABG}$ after $\mathrm{NaHCO}_{3}$ infusion was $\mathrm{pH} 7.35, \mathrm{Na} 134 \mathrm{mmol} / \mathrm{L}, \mathrm{K} 3.4 \mathrm{mmol} / \mathrm{L}, \mathrm{Cl}$ $104 \mathrm{mmol} / \mathrm{L}, \mathrm{HCO}_{3} 15.8$ and $\mathrm{BE} \mathrm{8}, \mathrm{PaO}_{2} 90 \mathrm{mmHg}$, and $\mathrm{PaCO}_{2} 37 \mathrm{mmHg}$. Thereafter his recovery was uneventful, and the child was discharged from the hospital on the $7^{\text {th }}$ postoperative day.

\section{Case report 2}

A 6-year-old female child weighing $19 \mathrm{~kg}$ was scheduled for limited posterior sagittal anorectoplasty for anovestibular fistula. Her preoperative hemoglobin was $12.4 \mathrm{~g} \%$, serum $\mathrm{Na} 138 \mathrm{mmol} / \mathrm{L}$, and Cl $102 \mathrm{mmol} / \mathrm{L}$. An evening before surgery TGI was started with NS and total volume used was $7.5 \mathrm{~L}$ over a period of $10 \mathrm{~h}$. On the morning of surgery, the child was lethargic and not communicating. She vomited once in the preanesthetic room. Her ABG showed $\mathrm{pH} 7.11$, $\mathrm{PaO}_{2} 93.5 \mathrm{mmHg}, \mathrm{PaCO}_{2} 33.6 \mathrm{mmHg}, \mathrm{HCO}_{3} 11.0 \mathrm{mmHg} / \mathrm{L}$, $\mathrm{BE} 16.4, \mathrm{Na} 132 \mathrm{mmol} / \mathrm{L}, \mathrm{K} 3.2 \mathrm{mmol} / \mathrm{L}$, and Cl $115 \mathrm{mmol} / \mathrm{L}$. An IV infusion of $5 \%$ dextrose in water with $50 \%$ of the calculated $\mathrm{NaHCO}_{3}$ was started. The child started showing improvement, became active and started communicating. The ABG after $\mathrm{NaHCO}_{3}$ infusion showed $\mathrm{pH} 7.36, \mathrm{Na} 135 \mathrm{mmol} / \mathrm{L}$, $\mathrm{K} 3.6 \mathrm{mmol} / \mathrm{L}, \mathrm{HCO}_{3} 20$ and $\mathrm{BE} 5$.

\section{Discussion}

Hyperchloremic metabolic acidosis has been reported after rapid IV infusion of large volumes of NS intraoperatively ${ }^{[6]}$ and in critically ill patients admitted to ICU. ${ }^{[7]}$

$\mathrm{NS}$ is composed of $154 \mathrm{meq} / \mathrm{L}$ of $\mathrm{Na}$ and $154 \mathrm{meq} / \mathrm{L}$ of $\mathrm{Cl}$ and hence is considered to be electrically neutral. When NS is infused, an equal amount of $\mathrm{Na}$ and $\mathrm{Cl}$ is added to the plasma. The plasma $\mathrm{Cl}$ increases to a greater degree because normal plasma $\mathrm{Cl}$ levels are less than $\mathrm{Na}$. This leads to narrowed strong ion difference (SID) and decreased net positive ion charge. Reduced SID leads to proton degeneration which is a compensatory response to restore charge equilibrium. This physiological process manifests as a decreased $\mathrm{pH}^{.}{ }^{[8]}$

The principle of TGI is that most of NS is unabsorbed. The increased intraluminal volume stimulates peristalsis throughout the bowel which leads to clearing of fecal matter from colon and rectum. ${ }^{[3]}$ The average duration of bowel preparation with NS depends on the rate of infusion and is $3.45 \mathrm{~h}(2) 7.3 \mathrm{~h}$ (1) at the infusion rates of $70 \mathrm{ml} / \mathrm{kg} / \mathrm{h}$ and $30 \mathrm{ml} / \mathrm{kg} / \mathrm{h}$, respectively.

In our institute, NS $30 \mathrm{ml} / \mathrm{kg} / \mathrm{h}$ is used for bowel preparation because this rate is associated with lesser complications of TGI. In our first patient, it took around $10 \mathrm{~h}$ to prepare the bowel and the total volume of NS used was $4.5 \mathrm{~L}$. It appears that the rate of infusion was not constant but probably $>30 \mathrm{ml} / \mathrm{h}$ which resulted in significant absorption of NS from the gut. Since the returning effluent was not clear, hence longer time was required for bowel preparation. In our second patient, the absorption of NS from the bowel probably occurred because of the partial obstruction due to the narrow opening of the anovestibular fistula.

Hyperchloremic metabolic acidosis is often iatrogenic and has been found to be associated with increased eicosanoid release in the renal tissue which may be the cause for decreased gastric mucosal perfusion, ${ }^{[9]}$ renal vasoconstriction and decreased glomerular filtration rate. It has also been associated with impaired coagulation, need for $\mathrm{HCO}_{3}$ buffering and use of more blood products. A large observational study, however, did not show that hyperchloremic metabolic acidosis was worse than no metabolic acidosis. ${ }^{[10]}$ Therefore, though not considered a predictor of outcome or mortality, it may be associated with hemorrhage risk, transfusion of more blood components and resource utilization.

Both our patients had an uneventful recovery with appropriate management. These two cases of hyperchloremic acidosis after TGI highlight the need to monitor the flow rate of NS used for TGI and monitor these children not only for electrolyte imbalance but also hyperchloremic acidosis.

\section{Financial support and sponsorship}

Nil.

\section{Conflicts of interest}

There are no conflicts of interest.

\section{RefEREnCES}

1. Postuma R. Whole bowel irrigation in pediatric patients. J Pediatr Surg 1982;17:350-2.

2. Chattopadhyay A, Prahash B, Vepakomma D, Nagendhar Y, Vijayakumar. A prospective comparison of two regimes of bowel preparation for pediatric colorectal procedures: Normal saline with added potassium vs. polyethylene glycol. Pediatr Surg Int 2004;20:127-9.

3. Hewitt J, Reeve J, Rigby J, Cox AG. Whole-gut irrigation in preparation for large-bowel surgery. Lancet 1973;2:337-40.

4. Davis GR, Santa Ana CA, Morawski SG, Fordtran JS. Development of a lavage solution associated with minimal water and electrolyte absorption or secretion. Gastroenterology 1980;78:991-5.

5. Kujat R, Grosse H, Gams E, Pichlmayr R. Changes in water-electrolyte balance after orthograde intestinal irrigation. Chirurg 1981;52:586-9.

6. Scheingraber S, Rehm M, Sehmisch C, Finsterer U. Rapid saline infusion produces hyperchloremic acidosis in patients undergoing gynecologic surgery. Anesthesiology 1999;90:1265-70.

7. Moviat M, van Haren F, van der Hoeven H. Conventional or physicochemical approach in intensive care unit patients with metabolic acidosis. Crit Care 2003;7:R41-5.

8. Miller LR, Waters JH. Mechanism of hyperchloremic nonanion gap acidosis. Anesthesiology 1997;87:1009-10.

9. Wilkes NJ, Woolf R, Mutch M, Mallett SV, Peachey T, Stephens R, et al. The effects of balanced versus saline-based hetastarch and crystalloid solutions on acid-base and electrolyte status and gastric mucosal perfusion in elderly surgical patients. Anesth Analg 2001;93:811-6.

10. Gunnerson KJ, Saul M, He S, Kellum JA. Lactate versus non-lactate metabolic acidosis: A retrospective outcome evaluation of critically ill patients. Crit Care 2006;10:R22. 